\title{
FeS-cluster coordination of vertebrate thioredoxins regulates suppression of hypoxia-induced factor $2 \alpha$ through iron regulatory protein 1
}

Carsten Berndt ${ }^{1 \star}$, Eva-Maria Hanschmann ${ }^{1,2}$, Claudia Urbainsky², Laura Magdalena Jordt $^{2}$, Christina Sophia Müller ${ }^{3}$, Yana Bodnar ${ }^{2}$, Susanne Schipper ${ }^{2,4}$, Oliver Handorf ${ }^{2,5}$, Ricardo Nowack ${ }^{6}$, Jean-Marc Moulis ${ }^{7}$, Carola Schulzke ${ }^{6}$, Volker Schünemann³, and Christopher Horst Lillig ${ }^{2 *}$

${ }^{1}$ Department of Neurology, Medical Faculty, Heinrich Heine University Düsseldorf, D40225, Germany, ${ }^{2}$ Institute for Biochemistry and Molecular Biology, University Medicine Greifswald, D-17475, Germany, ${ }^{3}$ Department of Physics, Technical University of Kaiserslautern, D-67663, Germany, "4Department of Biochemistry and Molecular Biology, Justus-Liebig University Gießen, D-35390, Germany, ${ }^{5}$ Leibniz Institute for Plasma Science and Technology, Greifswald, D-17489, Germany, ${ }^{6}$ Institute of Biochemistry, University of Greifswald, D-17487, Germany, ${ }^{7}$ Univ. Grenoble Alpes, CEA-IRIG and LBFA, Inserm U1055, Grenoble, F-38000, France

* correspondence:

Carsten Berndt, Department of Neurology, Heinrich-Heine University. Life Science Center, Merowingerplatz 1a, 40225 Düsseldorf, Germany, phone: +49 2118106041 , email: berndt@hhu.de

and

Christopher Horst Lillig, Institute for Medical Biochemistry and Molecular Biology, University Medicine Greifswald, Ferdinand-Sauerbruch-Strasse, 17475 Greifswald, Germany, phone: +49 3834 865407, email: horst@lillig.de 


\section{Abstract}

Thioredoxins (Trxs) provide electrons to essential cellular processes such as DNA synthesis. Here, we characterize human and murine Trx1 as new iron-sulfur proteins. The [2Fe-2S] cluster is complexed using cysteinyl side chains 32 and 73 in a dimeric holocomplex. Formation of the holo-dimer depends on small structural changes of the loop connecting helices three and four and is stabilized by the formation of a direct electrostatic interaction between Lys72 and Asp60 of two monomers. The not strictly conserved Cys73 in vertebrates co-evolved with the regulation of cellular iron homeostasis through the ironregulatory proteins (IRP). Active apo-Trx1 is required for the reduction of cysteinyl residues in IRP1 and its binding to the iron-responsive elements in the mRNA encoding hypoxiainducible factor (HIF) $2 \alpha$. Depletion of Trx1 increased the mRNA levels of HIF2 $\alpha$, an important target of IRP1. Hence, translation of the HIF2 $\alpha$ mRNA requires either sufficient iron-supply or the lack of reducing power of the Trx system under iron-limiting conditions. Only then, HIF2 $\alpha$ protein may accumulate under hypoxic conditions to transcriptionally regulate processes like erythropoiesis. 
bioRxiv preprint doi: https://doi.org/10.1101/2020.08.04.235721; this version posted August 5, 2020. The copyright holder for this preprint (which was not certified by peer review) is the author/funder. All rights reserved. No reuse allowed without permission.

Keywords: hypoxia-induced factor, iron-regulatory protein, iron metabolism, thioredoxin, iron-sulfur cluster 


\section{Significance Statement}

Thioredoxins are, in general, cofactor-less key proteins in redox regulation and provide electrons to many essential cellular processes such as DNA synthesis. 55 years after its discovery, we show that mammalian thioredoxin 1 coordinates an iron-sulfur cluster using one of its active site cysteinyl residues and a non-conserved additional cysteinyl residue located outside the active site. This particular residue co-evolved with the vertebratespecific iron regulatory system. Our study demonstrates that this system is regulated by thioredoxin 1 at the level of the iron-regulatory protein 1 , thus linking redox and iron homeostases. 


\section{Introduction}

Thioredoxin (Trx) is a small oxidoreductase catalyzing thiol-disulfide exchange reactions with two cysteinyl residues in its CxxC active site motif (overview in (1). Trxs are reduced by the dedicated NADPH-dependent flavo- and selenoenzyme Trx reductase (TrxR). Mammalian cells contain two pairs of Trx/TrxRs, i.e. cytosolic Trx1/TrxR1 and mitochondrial Trx2/TrxR2. Trxs were first described as electron donors for ribonucleotide reductase (2). Today, however, Trxs are better known as major regulators of various cellular functions through the redox-regulation of thiol-disulfide switches and other redox modifications in key proteins $(3,4)$.

Cellular functions, especially redox-controlled functions, depend on the presence of specific organic or inorganic cofactors. Among inorganic cofactors, iron has a prominent role as it can be incorporated e.g. as heme or iron-sulfur (FeS) center into proteins. These proteins are essential to facilitate transport of oxygen or electron transfer reactions, for instance in the respiratory chain, DNA replication and repair, mRNA translation and cellular metabolism (5). Iron deficiency can lead to anemia, iron overload can induce cellular toxicity and is associated with various pathologies. Frequently, these can be traced back to the formation of hydroxyl radicals via the so-called Fenton reaction, see for instance $(4,6)$. Because cellular iron levels need to be tightly controlled, organisms have developed effective mechanisms for iron regulation. Whereas lower organisms utilize transcriptional regulation mechanisms to control iron homeostasis, vertebrates have developed a posttranscriptional mechanism via iron regulatory proteins (IRPs) (7-9) at the cellular level that complements systemic, often transcriptional, regulations. Activities of IRP1 and IRP2 are regulated in different ways. IRP1 is active under iron deficiency, when its [4Fe-4S] cofactor is lost; the holo-protein functions as aconitase. Thus, the FeS cluster in IRP1 is considered to have an iron-sensing function (8). IRP2 on the other hand has not been demonstrated to bind an FeS cluster and is regulated via ubiquitinylation and proteasomal degradation. Ubiquitination depends on the F-box/LRR-repeat protein 5 (FBXL5), whose stability 
depends on a di-iron center $(10,11)$. IRPs 1 and 2 bind to specific mRNA structures, called iron responsive elements (IREs), for instance of the iron import protein transferrin receptor (TfR), the iron storage protein ferritin, and the iron export protein ferroportin. Since approximately ten years it has been known that also the $5^{\prime}$ UTR of hypoxia inducible factor $2 \alpha$ (HIF2 $\alpha)$ mRNA contains an IRE $(12,13)$. Although both IRPs are able to bind this IRE (12), in vivo experiments suggest that IRP1 dominates the suppression of HIF2 $\alpha$ mRNA translation under iron-limiting conditios (12-16).

HIF2 $\alpha$ is a critical part of the hypoxic response signaling pathway. In the presence of oxygen, the alpha subunits of all hypoxia-inducible factors are hydroxylated at conserved proline residues by specific HIF prolyl-hydroxylases. These hydroxylated forms are flagged for proteasomal degradation by the von-Hippel-Lindau E3 ubiquitin ligase (17). In the absence of oxygen, i.e. hypoxia, hydroxylation fails and the proteins translocate into the nucleus where they act as transcription factors. HIF2 $\alpha$ controls, most importantly, erythropoiesis (18) and the growth and progression of various forms of cancer (19).

Redox regulation, iron homeostasis, and the hypoxic response strongly depend on each other. Until now, however, mechanistic insights into these crosstalks are sparse. Here, we show, that human and murine cytosolic Trx1s coordinate a [2Fe-2S $]^{2+}$ cluster and explain the structural changes allowing the coordination of the cofactor. The loss of this FeS center activates the thiol-disulfide oxidoreductase activity of the protein. Active Trx1 is required for the reduction of cysteinyl residues in apo-IRP1, a prerequisite for their binding to IREs. The suppression of HIF2 $\alpha$ translation under hypoxic - but iron-limited - conditions depends critically on the reductive capacity of the cytosolic Trx1/TrxR1/NADPH system. 


\section{Results}

During regular purification of recombinant Trxs expressed in E. coli, we noted a distinct brown-yellowish color of the human and mouse Trx1 proteins.

\section{Mammalian Trx1s complex a [2Fe-2S] ${ }^{2+}$ cluster}

The UV-Vis spectra of the recombinant human and mouse proteins freshly purified from $E$. coli cultures display two peaks at approx. 335 and $420 \mathrm{~nm}$, in addition to the peak of the aromatic side chains at $280 \mathrm{~nm}$ (Fig. 1A). These absorption features are characteristic for FeS clusters. The human protein was also subjected to gel filtration chromatography, where it separated into a monomeric and a dimeric fraction (Fig. 1A inset). From these, only the dimeric fraction displayed the additional absorption features, whereas the monomeric fraction was completely devoid of them (Fig. 1A).

An ideal method for the identification and characterization of iron centers is Mössbauer spectroscopy. Hence, apo-human Trx1 was subjected to FeS cluster reconstitution for the enrichment of the holo complexes with ${ }^{57} \mathrm{Fe}$. Mössbauer spectra were recorded for holoTrx1 in the absence (Fig. 1B) and presence of external magnetic fields (Fig. S1A-B †Supplementary Informations). The spectra were simulated with two components (fractions 1 and 2) with a relative contribution of ca. $20 \%$ and $80 \%$, respectively (Fig. 1B, Fig. S1A-B, Tab. 1, Tab. S1). Fraction 1 shows an isomer shift of $\delta=0.35 \mathrm{~mm} \mathrm{~s}^{-1}$ and a quadrupole splitting of $\Delta \mathrm{E}_{\mathrm{Q}}=0.66 \mathrm{~mm} \mathrm{~s}^{-1} . \delta$ is slightly higher than the values reported for high spin $\mathrm{Fe}^{3+}(\mathrm{S}=5 / 2)$ in a tetrahedral sulfur environment $\left(\delta=0.20-0.32 \mathrm{~mm} \mathrm{~s}^{-1}\right)(20)$. It is important to note that both $\delta$ and $\Delta \mathrm{E}_{\mathrm{Q}}$ are significantly smaller than those reported for $[4 \mathrm{Fe}-4 \mathrm{~S}]^{2+}$ clusters (21). The simulations of the spectra recorded in an external field of $0.1 \mathrm{~T}$ (Fig. S1A) and $5 \mathrm{~T}$ (Fig. S1B) are based on a diamagnetic species for fraction 1. Hence we conclude that this fraction represents a diamagnetic $[2 \mathrm{Fe}-2 \mathrm{~S}]^{2+}$ cluster in which the antiferromagnetic coupling of the two paramagnetic $\mathrm{Fe}^{3+}$ ions results in a $\mathrm{S}=0$ state (20-22). Fraction 2 is characterized by $\delta=0.56 \mathrm{~mm} \mathrm{~s}^{-1}$ and $\Delta \mathrm{E}_{\mathrm{Q}}=0.72 \mathrm{~mm} \mathrm{~s}^{-1}$. These 
Mössbauer parameters are characteristic for high spin $\mathrm{Fe}^{3+}$ with octahedral nitrogen or oxygen coordination. The broad magnetic pattern observed at $4.6 \mathrm{~K}$ and fields of 0.1 and 5 T indicate the presence of small super-paramagnetic clusters that could originate from side reactions during the reconstitution process, possibly also from the decomposition of [2Fe$2 S]^{2+}$ clusters $(23,24)$.

The Mössbauer spectra of fraction 1 demonstrate the presence of $[2 \mathrm{Fe}-2 \mathrm{~S}]^{2+}$ clusters in dimeric holo-Trx1. Reconstitution of the FeS cluster in Trx1 revealed approximately $30 \pm$ $14 \%$ holo-Trx1 (Mössbauer and UV-Vis spectroscopy), $40 \pm 16 \%$ of Trx1 were in the holoform directly after purification from E. coli (UV-Vis spectroscopy). To identify the residues responsible for the coordination of the cluster, we individually mutated each of the five Cys residues of human Trx1 to Ser. The stability of the mutants was confirmed by differential scanning calorimetry (Fig. S2, Tab. S2). Only the loss of two Cys residues led to the loss of the cluster binding, i.e. the more N-terminal active site residue C32 and the extra C73 outside the active site (Fig. 1C).

Can a $[2 \mathrm{Fe}-2 \mathrm{~S}]^{2+}$ cluster be complexed at the dimeric interface of two Trx molecules by a pair of C32/C73 ligands as simulated in Fig. 1D? In various structures of human Trx1 deposited in the protein data bank, the sulfur groups of these two residues are separated by a distance of approx. $10 \AA$ (Fig. S3A). This distance is too far for the joint coordination of the cofactor. However, as demonstrated by molecular modeling, only a small conformational change of the loop connecting helix 3 and strand 4 may bring the two sulfur atoms in a perfect distance for the coordination of the cluster, i.e. $3.4 \AA$ (Fig. S3A). A small conformational difference between holo- and apo-Trx1 was confirmed by CD spectroscopy (Fig. 1E). These changes are proposed to go along with conformational changes of the two Trp31 residues (Fig. 1D), that should alter the local environment of the indole ring systems. In fact, formation of the holo complexes induces quenching of the fluorescence of these (only) tryptophanyl residues (Fig. 1F). The solvachromatic nature of the Trp residues makes it sensitive to changes in the local environment polarity (25). Quenching can arise 
both from changes in the interaction with the solvent water molecules as well as altered interactions with other side chains in the complex. The conformational changes of the loop structure proposed to accommodate [FeS] binding also affect the orientation of lysyl residue $\mathrm{K} 72$. Our model suggests that the dimeric holo complex may be stabilized by a direct interaction between the $\varepsilon$-amino groups of the $\mathrm{K} 72$ residues with the carboxyl groups of the aspartyl residues D60 of the respective other subunit (Fig. 1D). In line with this hypothesis, Trx1K72E lost the spectral characteristics of the $[2 \mathrm{Fe}-2 \mathrm{~S}]^{2+}$ cluster coordinated by Trx1wt (Fig. S3B), while redox activity was only affected to a minor degree. The mutated form was still able to reduce insulin disulfides and can be reduced by TrxR1. The $K_{m}$ of TrxR1 towards Trx1K72E increased from $3.0 \pm 0.2$ to $4.4 \pm 1.7 \mu \mathrm{mol} \cdot \mathrm{I}^{-1}$, the $v_{\max }$ slightly increased from $2.7 \pm 0.1$ to $3.1 \pm 0.5 \mathrm{~s}^{-1}$ (Fig. S3C). The decreased affinity of TrxR for Trx1K72E was likely the result of changes in the electrostatic properties of the mutant (Fig. S3D-E). All these data confirm the formation of a holo-dimer using cysteinyl residues C32 and C73 as FeS cluster ligands. C73 is neither present in the mammalian mitochondrial Trx2, nor in bacterial Trxs, and none of these proteins contain a chromophore.

Does human Trx1 bind the iron cofactor also in vivo as suggested by incorporation of the FeS clusters into Trx1 during recombinant expression in E. coli (Fig. 1A)? To answer this question, we propagated Jurkat cells of human origin in the presence of transferrin-bound radioactive ${ }^{55} \mathrm{Fe}$. Trx1 and, as control, glutaredoxin (Grx) 1 that does not bind iron $(26,27)$, were immuno-precipitated from the cell extract and analyzed by scintillation counting for iron binding. Significant amounts of iron co-precipitated with Trx1, but not with Grx1 (Fig. S4).

\section{Trx1 and cellular iron metabolism}

Since FeS cluster coordination blocks the CxxC active site, we assumed a Trx1-dependent connection between redox and iron regulation. Using Trx1C35S, a mutant lacking the 
second resolving cysteinyl residue of the active site, we were able to trap and identify potential substrates of Trx1 in HeLa cells. IRP1, the post-transcriptional iron regulator located in the cytosol of mammalian cells, was one of these substrates (Fig. S5A). In addition, Trx1 was confirmed as interaction partner of IRP1 using co-immunoprecipitation under normoxic and hyperoxic conditions in Jurkat cells (Fig. S5B). Based on this, we analyzed the consequence of Trx1 depletion on the level of IRP1-regulated proteins. Since IRP1 is also an important regulator of hypoxia response, HeLa cells were cultivated at $1 \%$ oxygen to inhibit the proteasomal degradation of HIF2 $\alpha$ and treated with the iron-chelator deferoxamine (DFO), thus provoking both iron-depletion and hypoxia responses. Using siRNA, Trx1 levels were lowered to approx. 35\% (Fig. 2), which showed only a moderate effect on iron regulation. Depletion of Trx1 had no significant effect on the diminished cytosolic FeS cluster biogenesis as shown by the levels of GPAT (Fig. 2), a metabolic enzyme that is degraded when incorporation of its FeS cluster fails. In control cells, the iron storage protein ferritin was decreased under iron-limiting conditions (61 $\pm 6 \%$ ), caused by binding of IRPs to the IRE in the 5' region of the mRNA, consequently inducing a translational block. This block, however, did not occur when Trx1 was depleted (102 \pm 9 $\%$, Fig. 2). The increase in the levels of the TfR upon iron limitation (binding of IRPs to the IRE in the 3' region of the mRNA), was not affected by Trx1 deficiency (Fig. 2). Similar to ferritin, the HIF2 $\alpha$ mRNA contains an IRE in its 5' region. Hence, iron depletion led to a translational block and a decrease in the levels of HIF $2 \alpha$ protein to about $32 \%$. With depleted Trx1 levels, this block was not only absent, the levels of HIF2 $\alpha$ even increased 3.5-fold (Fig. 2).

\section{Human Trx1 reduces Iron-Regulatory Protein 1 in vitro and in vivo}

Next, we tested recombinant oxidized human apo-IRP1 as substrate for Trx1 in a coupled assay with TrxR1 following NADPH consumption. As depicted in Fig. 3A, Trx1 was able to reduce and thus activate IRP1 in vitro with a $K_{m}$ of $18.5 \mu \mathrm{M}$ and a $v_{\max }$ of $0.41 \mathrm{~s}^{-1}$. 
Does Trx1 also fulfill this function in vivo? We analyzed the redox state of IRP1 in Trx1depleted HeLa cells using specific siRNA compared to cells treated with control siRNA via two dimensional diagonal gel electrophoresis. In the first dimension, the proteins were separated by non-reducing SDS PAGE, the second dimension was SDS PAGE under reducing conditions. In this assay, reduced proteins end up on the diagonal according to their molecular weight (Fig. 3B-C). Proteins with oxidized cysteinyl residues, however, drop below the diagonal. As demonstrated by an overlay of Coomassie-stained gel (blue) and Western blot detecting IRP1 (black), all IRP1 in control cells was in the reduced state (Fig. 3B). Upon Trx1-depletion, however, most of the IRP1 protein was oxidized (Fig. 3C). Apparently, Trx1 is required for the reduction, and thus activation, of IRP1 in vivo. Accordingly, lower levels of Trx1 led to decreased aconitase activity in the cytosol of hypoxic HeLa cells under iron depletion (Fig. S6), whereas the protein level of aconitase/IRP1 was not affected (Fig. 2).

\section{Trx1 regulates IRP1 binding to the Hif2 $\alpha-I R E$}

The HIF2 $\alpha$ mRNA has been demonstrated to be one of the major targets of IRP1 (16). How did the depletion of Trx1 inhibit IRP1 activity as inhibitor of HIF2 $\alpha$ translation? It has long been known from in vitro assays that the binding of IRP1 to IREs requires the reduction of the cysteinyl residues in the IRE binding site, see e.g. (28). These residues are also the residues coordinating the FeS cluster within IRP1 that is lost upon iron depletion. Apparently, this leaves these cysteinyl residues in an oxidized state. Whereas Trx1 depletion via siRNA (Fig. S7A) showed no impact on IRP1/HIF2 $\alpha$-IRE binding in whole lysates of cells cultivated under standard conditions, the increased IRP1/HIF2 $\alpha$-IRE binding under iron limited and hypoxic conditions (307 $\pm 63 \%$ compared to untained cells) was severely inhibited in Trx1-depleted HeLa cell lysates (213 $\pm 58 \%)$ in electrophoretic mobility shift assays (EMSAs, Fig. 3D). This inhibited IRE binding capacity was even more pronounced in the purified cytosolic fraction (39 $\pm 28 \%$ compared to $60 \pm 18 \%$ in whole lysate, Fig. S7B). Moreover, the isolated cytosolic fraction showed decreased IRE binding 
in EMSAs under standard conditions (Fig. S7B). Formation of supershift complexes after addition of anti-IRP1-antibodies confirmed IRP1-IRE probe complexes (Fig. S7C and S7E). The reduction of lysates with DTT showed that decreased complex formation upon Trx1 depletion is not based on decreased levels of IRP1 (Fig. S7D). EMSAs with purified recombinant IRP1 and Trx1 demonstrated direct reduction and activation of IRP1 by Trx1. $10 \mu \mathrm{M}$ of $\operatorname{Trx} 1$ is as efficient as $10 \mathrm{mM} \beta$-mercaptoethanol in the activation of $1 \mu \mathrm{M}$ IRP1 (Fig. S7E). The blocking of the CxxC active site by coordination of the FeS cluster diminished the ability of Trx1 to activate IRP1 to $31 \pm 5 \%$, whereas incubation with $\mathrm{Fe}^{2+}$ most likely leading to unspecific iron binding had almost no effect on Trx1 activity (82 \pm 22 \%, Fig. 3E). 


\section{Discussion}

In the present study, we characterized the human and murine cytosolic Trx1 as new FeSproteins. The $[2 \mathrm{Fe}-2 \mathrm{~S}]^{2+}$ cluster is coordinated at the dimeric interface of two Trx molecules. Approximately a decade ago, we have characterized human Grx2 as the first member of the Trx family, that contains an FeS cofactor (27). The $[2 \mathrm{Fe}-2 \mathrm{~S}]^{2+}$ cluster in Grx2 is coordinated by the N-terminal active site Cys of two monomers plus two additional non-covalently bound glutathione molecules $(29,30)$. Because the glutathione used as FeS ligand is in permanent exchange with the free pool of glutathione, the iron complex was described as a redox sensor that could regulate the oxidoreductase activity depending on the redox state of the free glutathione pool (29). Holo-Grx2 is inactive as oxidoreductase, but appears to be involved in nitric oxide detoxification during neuroinflammation (31). Enzymatically active apo-Grx2 is required, for instance, for brain and vascular development $(32,33)$, and promotes cell migration of cancer cells $(34)$. The same mode of cluster coordination was also demonstrated for the human monothiol Grxs 3 and $5(26,35)$ that function in iron homeostasis and FeS cluster biosynthesis, as well as for various Grxs from other species, for overviews see for instance $(36,37)$. Fig. 4A depicts the overlay of the iron-coordinating thiol groups in human Trx1, Grx2, and Grx5, centered on the common N-terminal active site cysteinyl residue (C32 in Trx1) indicating that FeS cluster coordination by Trx family proteins needs a second thiol group in the suitable distance range to the active site thiol. Whereas Grxs insert this thiol via the bound glutathione, human Trx1 uses as second thiol the side-chain of the not universally conserved C73. The position of this second thiol appears to be variable, due to the dimeric nature of the holo-complexes. The slightly shifted positions of the glutathione thiols and FeS centers are caused by alternative loop structures preceding the active sites. These differences are also the structural basis for the functional difference between the two classes of glutaredoxins (38). The different positions of the glutathione thiol cause a rotation of the two Grx monomers in the Grx2 and Grx5 holo-complexes relative to each 
other $(30,35)$. Likely, this is also true for the Trx1 holo-complex, although Mössbauer spectroscopy revealed a slightly higher value of $\delta$ than found usually for [2Fe-2S] clusters coordinated by four sulfhydryl groups. This increase could be related to the presence of a nitrogen or an oxygen ligand $(20,22)$. Recently, for the bishistidinyl-coordinated nonRieske $[2 \mathrm{Fe}-2 \mathrm{~S}]^{2+}$ proteins a value of $\delta=0.36 \mathrm{~mm} \mathrm{~s}^{-1}$ has been reported for the bis-histidyl coordinated $\mathrm{Fe}^{3+}$ site at $\mathrm{pH}=6$ (39). However, the only nitrogen or oxygen available for cluster coordination near the active site would be the histidyl residues introduced by the His-tag. Since we used both, C- as well as N-terminal His-tags, and were able to show that specific Trx1 mutants affect cluster coordination independent on the His-tag, we are confident that the cofactor is coordinated by cysteinyl residues 32 and 73 . In retrospect, this coordination was already indicated by our own work showing that only the additional removal of these two cysteinyl residues in human Trx1 inhibited [2Fe-2S] cluster coordination in a mutant lacking the cis-proline (P75 in human Trx1), another factor regulating FeS cluster coordination in members of the Trx family (40). However, recently a [4Fe-4S] cluster coordinated by the residues of the two active side cysteinyl residues was described in A. thaliana Trx o (41). This Trx is located in mitochondria, contains a cis-prolyl residue, and lacks the additional $\mathrm{C} 73$ which serves as second thiol in a similar position as in the FeS-Grxs. C73 is not an ubiquitously conserved residue. We have performed an extensive sequence comparison between Trxs from various species, classes, and kingdoms, see Fig. S8. This analysis identified the extra C73 as specific for vertebrate Trxs, with only few exceptions in arachnid species and one mollusk. C73 is not present in Trxs from bacteria, fungi, plants, insects, and nematodes. Hence, nearly all potential FeSTrxs exist in the same evolutionary group that utilize the IRP/IRE system for the regulation of iron-uptake and storage (also included in Fig. S8); all of the C73-Trxs are cytosolic proteins. Only one previous study linked Trx1 to the IRP regulon. In macrophages, Trx1 was reported to be required for the activation of IRP1 after exposure to nitric oxide (42). Trx1 is able to reduce IRP1 in vitro and in vivo leading to increased IRE binding of HIF2 $\alpha$ 
mRNA (Fig. 3). The importance of the reduction of the cysteinyl residues in the FeS cluster coordination site of IRP1, that is also the IRE binding site, has long been known from in vitro assays e.g. (28). Here, we focus on the redox state of cysteinyl residues. However, also other amino acids may contribute to the redox regulation of IRP1 activity, i.e. tyrosine nitration by peroxynitrate (43). When iron is not limiting, IRP1 (gene name ACO1) is a functional cytosolic aconitase with a [4Fe-4S] cluster in its active site that is ligated by three cysteinyl residues. This cluster is lost when iron becomes a limiting factor, IRP1 undergoes structural changes between holo- and apo-form, and the resulting apo-protein can bind IRE stem loop structures in mRNAs (Fig. S9A). The three cysteinyl residues essential for both FeS cluster coordination and IRE binding C437, C503, and C506 are close together in the holo-form (approximately $6 \AA$ ), but shift 18.2, 22.8, and $27.4 \AA$, respectively, to their positions in the apo-form where the distance between $\mathrm{C} 437$ and $\mathrm{C503}$ or C506 is 12.5 and $17 \AA$ (Fig. S9B). The redox state of C437 has been described before as important for IRE binding (44). Only mutation of this cysteinyl residue rescued the lost IRP1-IRE binding upon treatment with either N-ethyl-maleimide, a molecule blocking free thiols, or diamide, a compound that unspecifically induces the formation of disulfides. Of course, formation of a disulfide needs two cysteinyl residues. The interaction between Trx and a substrate critically depends on complementary electrostatic properties $(45,46)$. Based on the electrostatic surface potential maps of apo-IRP1 and apo-Trx1, we predict that the active site of Trx1 most likely attacks either C503 or C506 (Fig. S9C). Therefore, we hypothesize the formation of a disulfide between cysteinyl residues 437 and 503/506 after disassembly of the FeS cluster inhibiting the formation of the open apo-form of IRP1 and subsequently IRE binding. The formation of a disulfide that may prevent IRE-binding was suggested before (47). This is, however, in contrast to several reports describing the activation of IRP1 by $\mathrm{H}_{2} \mathrm{O}_{2}$, summarized in (48). Noteworthy, this activation can be observed only at low concentrations of $\mathrm{H}_{2} \mathrm{O}_{2}$ in cells and not in lysates. In intact cells, low levels of $\mathrm{H}_{2} \mathrm{O}_{2}$ most likely activate the Keap1/Nrf2 system, which leads to the expression of 
various enzymes counteracting oxidative damage, including Trx1, that subsequently promote the activation of IRP1.

Lack of Trx1 led to a massive increase in HIF2 $\alpha$, despite iron-limitation conditions, while other iron-regulated proteins were hardly affected (Fig. 2). The block of ferritin translation was absent in Trx1-depleted cells, but the increase in TfR levels was similar. This was expected, as TfR expression is stimulated under hypoxia via hypoxia responsive elements in its promotor region (49). Mammalian IRP1 and IRP2 share functions (50), but are differently effected by hypoxia: IRP1 is inhibited, while IRP2 is activated $(51,52)$, although data that suggest the activation of IRP1 during hypoxia have also been presented $(53,54)$. Several studies, including analyses of knock-out mice, emphasized the pivotal function of IRP1 in the suppression of HIF2 $\alpha$ translation under iron limiting conditions (14-16). HIF2 $\alpha$ is an essential regulator of erythropoiesis and angiogenesis, as well as cell proliferation, de-differentiation, and invasion of cancer cells via its various target proteins $(16,18,19$, 55).

HIF2 $\alpha$ is primarily regulated by suppression of its translation through IRP1 under ironlimiting conditions and the $\mathrm{O}_{2}$-dependent proteasomal degradation pathway. This study adds a third level of regulation to the IRP1-HIF2 $\alpha$ signaling hub, i.e. redox regulation. The lack of Trx1 activity in cells leads to the loss of HIF2 $\alpha$ suppression even under ironlimitation conditions. Fig. 4B summarizes this extended model of IRP1 activation and thus permission or suppression of HIF2 $\alpha$ translation. Activation of both Trx1 and IRP1 requires conditions that lead to the loss of their iron-sulfur cofactors (Fig. 3E). Next, activation of IRP1 requires the reduction of the protein by Trx1 with electrons donated by TrxR1 and NADPH. Limitation of the reducing power of the Trx system may explain the limited ability of IRP to regulate exogenous IREs in transfected cellular systems (56). Only when both conditions are met, iron limitation and sufficient reducing power of the cytosolic Trx system, IRP1 can bind to the IRE in the 5'-end of the HIF2 $\alpha$ mRNA and thus suppresses its translation and accumulation of the factor under hypoxic conditions. In support of this 
bioRxiv preprint doi: https://doi.org/10.1101/2020.08.04.235721; this version posted August 5, 2020. The copyright holder for this preprint (which was not certified by peer review) is the author/funder. All rights reserved. No reuse allowed without permission.

model, all mentioned HIF2 $\alpha$ processes are also redox-regulated on multiple levels, many of which are dependent on Trx1, summarized in (4). 


\section{Methods}

\section{Cloning, protein expression and purification:}

Human Trx1 was cloned into the expression plasmid pet20b as described before (57). Mutations were inserted by rolling circle mutagenesis using specific oligonucleotides (C32S: fwd: cagccacgtggtctgggccttg, rev: caaggcccagaccacgtggctg; C35S: fwd: tggtgtgggccttccaaaatgatc, rev: gatcatttggaaggccacacca; C62S: fwd: gtggatgactctcaggatgttgc, rev: gcaacatcctgagagtcatccac; C69S: fwd: gttgcttcagagtctgaagtcaaatg, rev: catttgacttcagactctgaagcaac; C73S: fwd: gaagtcaaatccatgccaacattcc, rev: ggaatgttggcatggatttgacttc; K72E: fwd: tcagagtgtgaagtcgagtgcatgccaacattc, rev: gaatgttggcatgcactcgacttcacactctga). IRP1 was cloned by PCR from human cDNA using specific oligonucleotides (fwd: gctagcatgagcaacccattcgcac, rev: ctcgagcttggccatcttgcggatcatg), digested with Nhel and Xhol, and cloned into the vector pET16b (Novagen). Proteins were produced in E. coli as His-tag proteins and were purified using the IMAC principle (GE healthcare). Following purification, proteins were buffered in PBS using NAP-5 columns (GE healthcare) or Zeba spin columns (Thermo Scientific). The thermal stability of Trx1 mutated forms was analyzed using differential scanning calorimetry. $40 \mu \mathrm{M}$ of the proteins in PBS were heated from 20 to $100^{\circ} \mathrm{C}$ at $1 \mathrm{~K}$ per minute in a Micro Cal VP-DSC (Malvern Panalytical Ltd) and the heat flux was recorded. Gelfiltration chromatography for the separation of monomeric and dimeric Trx1 was performed as outlined in (26).

\section{In vitro reconstitution}

Reconstitution of the FeS cluster was performed as described in (29) without GSH. For Mössbauer spectroscopy apo-Trx1 was reconstituted using $\left(\mathrm{NH}_{4}\right)_{2}{ }^{57} \mathrm{Fe}\left(\mathrm{SO}_{4}\right)_{2}$ as iron source. 


\section{Spectroscopy}

Following purification, reconstitution, and buffering in PBS, proteins were desalted using NAP-5 columns, UV-Vis spectra were recorded using 100-250 $\mu \mathrm{M}$ of wildtype and mutant proteins with the Uvikon 922 photometer (Kontron Instruments) from 240-720 nm. Circular dichroism (CD) spectra were recorded with $10 \mu \mathrm{M}$ apo- and holo-Trx1 in a $1 \mathrm{~mm}$ cuvette, scanning $0.2 \mathrm{~nm}$ steps, averaging 5 iterations, with the Jasco $\mathrm{J}-810$ instrument. Tryptophanyl fluorescence was recorded with a Perkin Elmer LS50B fluoriometer (10 $\mu \mathrm{mol} \cdot \mathrm{I}^{-1}$ protein, excitation: $296 \mathrm{~nm}, 6 \mathrm{~nm}$ excitation slit and $4 \mathrm{~nm}$ emission slit).

A conventional Mössbauer spectrometer was operated in the constant acceleration mode in conjunction with a multichannel analyzer in the time-scale mode (WissEl GmbH) to record transmission Mössbauer spectra. The spectrometer was calibrated against $\alpha$-iron at room temperature. The samples were cooled to $77 \mathrm{~K}$ with a flow cryostat (OptistatDN, Oxford Instruments). Field-dependent conventional Mössbauer spectra were obtained with a helium closed-cycle cryostat (CRYO Industries of America, Inc.) equipped with a superconducting magnet (58). The magnetic field was aligned parallel to the y-ray beam. The spectral data were transferred from the multichannel analyzer to a PC for further analysis employing the public domain program Vinda (59) running on an Excel (2003) platform. Analysis of the spectra was performed by least-squares fits using Lorentzian line shapes with the linewidth $\Gamma$. Field-dependent spectra were simulated by means of the spin Hamilton formalism (60). Following in vitro reconstitution, human Trx1 was concentrated to $2.5 \mathrm{mM}$ using the Stirred Ultrafiltration Cell (Millipore) and buffered in PBS using PD-10 columns (GE Healthcare). $\left(\mathrm{NH}_{4}\right)_{2}{ }^{57} \mathrm{Fe}\left(\mathrm{SO}_{4}\right)_{2} \cdot 6 \mathrm{H}_{2} \mathrm{O}$ was synthesized in a procedure adapted from (61). In brief, $102.9 \mathrm{mg}(1.768 \mathrm{mmol}, 1 \mathrm{eq})$ of ${ }^{57} \mathrm{Fe}$ were dissolved in $2.6 \mathrm{ml}$ of 1 molar sulfuric acid with continuous heating under $\mathrm{N}_{2}$ atmosphere. The resulting turquoise solution was filtered from the deposited coke. To this solution, $243.14 \mathrm{mg}$ (1.84 mmol, 1 eq) ammonium sulfate in aqueous solution were added. Next, the solution was concentrated under reduced pressure and allowed to form a crystalline surface; the 
concentrated solution was heated and stored by $4^{\circ} \mathrm{C}$ to allow crystallization. The resulting turquoise crystals were collected and the procedure was repeated for the remaining solution. In the end, $67.7 \%$ of the initial iron was present as highly pure $\left(\mathrm{NH}_{4}\right)_{2}{ }^{57} \mathrm{Fe}\left(\mathrm{SO}_{4}\right)_{2} \cdot 6 \mathrm{H}_{2} \mathrm{O}$ crystals, as confirmed by X-ray analysis (62).

\section{Activity measurements}

The activity of cytosolic aconitase was determined as described in (63). The activity of Trx1 in the reduction of IRP1 was measured in a coupled optical assay with rat thioredoxin reductase and NADPH as outlined in (64). The reduction of insulin in a coupled assay of Trx with TrxR has been performed following the reduction of NADPH spectrophotometrically. The assay mixture contained $50 \mathrm{mmol} \cdot \mathrm{I}^{-1} \mathrm{Tris} / \mathrm{HCl} \mathrm{pH} \mathrm{7.5,2} \mathrm{mmol} \cdot \mathrm{I}^{-}$ 1 EDTA, $160 \mu \mathrm{mol} \cdot \mathrm{I}^{-1}$ insulin (SIGMA-Aldrich), $150 \mu \mathrm{mol} \cdot \mathrm{I}^{-1} \mathrm{NADPH}, 1.25 \mathrm{nmol} \cdot \mathrm{I}^{-1}$ recombinant rat TrxR1 (kind gift from Elias Arner, Stockholm), and Trx from $0-25 \mu \mathrm{mol} \cdot \mathrm{I}^{-1}$.

\section{Cell culture}

HeLa cells were cultured in low glucose (1g/l) DMEM medium, supplemented with $10 \%$ FCS and 100 units $/ \mathrm{ml}$ penicillin $0.1 \mathrm{mg} / \mathrm{ml}$ streptomycin at $37{ }^{\circ} \mathrm{C}$ in a humidified atmosphere containing $5 \% \mathrm{CO}_{2}$. Cells were transfected with specific siRNA against human Trx1 by electroporation. $3.5 \cdot 10^{6}$ cells were resuspended in electroporation buffer (21 mM HEPES, $137 \mathrm{mM} \mathrm{NaCl}, 5 \mathrm{mM} \mathrm{KCl}, 0.7 \mathrm{mM} \mathrm{Na}_{2} \mathrm{HPO}_{4}, 6 \mathrm{mM}$ D-glucose, pH 7.15), were mixed with $15 \mu \mathrm{g}$ of Trx1 siRNA (sense: guagauguggaugacuguc, antisense: gacagucauccacaucuac) or scrambled control siRNA (sense: cauucacucaggucauca, antisense: cugaugaccugagugaau) and were electroporated at $250 \mathrm{~V}, 1500 \mu \mathrm{F}$ and $500 \Omega$ using the BTX ECM 830. FCS was immediately added to the cells before seeding them in 1:5 conditioned medium. The following day the medium was changed. For sufficient knockdown, cells were transfected a second time after three days and cultivated for another 2 days at $20 \%$ oxygen followed by $24 \mathrm{~h}$ at $1 \%$ oxygen concentration. To reduce intracellular iron levels, cells were treated for $24 \mathrm{~h}$ with $100 \mu \mathrm{M}$ deferoxamine (Abcam). Cells were harvested by trypsination, incubated with PBS containing $100 \mathrm{mM}$ NEM for 30 min at 37 
${ }^{\circ} \mathrm{C}$. Cells were centrifuged and washed once in PBS, before 30 min lysis in $40 \mathrm{mM}$ HEPES, $50 \mathrm{mM} \mathrm{NaCl}, 1 \mathrm{mM}$ EDTA, $1 \mathrm{mM}$ EGTA, 2 \% CHAPS, complete protease inhibitor, and $5 \mathrm{mM} \mathrm{NEM}$. Samples were stored at $-80^{\circ} \mathrm{C}$. The knock-down efficiency, as well as the iron depletion was analyzed by Western blot using specific antibodies against Trx1 and iron-regulated proteins. Samples for Hif2 $\alpha$ were directly lysed after harvesting. $1 / 10^{\text {th }}$ of the cell pellet was washed once in PBS, centrifuged for 2 min at $1000 \mathrm{rpm}$ and lysed in 2x sample buffer.

Jurkat cells were cultured in RPMI medium supplemented with 10\% FCS, 100 units/ml penicillin and streptomycin, and $2 \mathrm{mM}$ glutamine at $37^{\circ} \mathrm{C}$ in a humidified atmosphere containing 5\% $\mathrm{CO}_{2}$. Radiolabeling was done with $1 \mathrm{mCi}, 2 \mu \mathrm{M}$ transferrin- ${ }^{55} \mathrm{Fe}$ (PerkinElmer). Co-immunoprecipitation of ${ }^{55} \mathrm{Fe}$ with $\operatorname{Tr} \times 1$ and Grx1 was performed as described for Grx3 in (26).

Cell fractionation was performed according to (63). Cells were resuspended in mitobuffer (5 mM Tris/HCl, $250 \mathrm{mM}$ Sucrose, $1 \mathrm{mM}$ EDTA, 1 mM EGTA, $1.5 \mathrm{mM} \mathrm{MgCl}$, 1mM PMSF, $\mathrm{pH}$ 7.4), containing $0.008 \%$ digitonin, and were incubated for 10 min on ice. Cells were centrifuged for $10 \mathrm{~min}$ at $15.000 \mathrm{~g}$ at $4{ }^{\circ} \mathrm{C}$. The supernatant was collected as cytosolic fraction. The pellet was washed 2 times, was resuspended in mitobuffer and collected as organelle-fraction.

\section{Electrophoresis, Electrophoretic mobility shift assay, and Western blotting}

Cell lysates were thawn on ice and centrifuged at $4^{\circ} \mathrm{C}$ for $15 \mathrm{~min}$ at $13.000 \mathrm{rpm}$. The protein content of the supernatants was analyzed according to Bradford (BioRad). 20-30 $\mu \mathrm{g}$ of total protein were diluted in sample buffer $(0.3 \mathrm{M}$ Tris/ $\mathrm{HCl}, \mathrm{pH} 7,50 \%$ glycerol, $5 \%$ SDS, $1 \mathrm{mM}$ EDTA, 0.1\% bromphenol blue), were reduced with $100 \mathrm{mM}$ DTT for $20 \mathrm{~min}$ at RT. Proteins were separated by SDS PAGE using Mini-Protean TGX stain-free 4-20\% precast gels (BioRad). 
For the electrophoretic mobility shift assay (EMSA), we synthesized IRD700 labeled RNA used as Hif2 $\alpha-I R E$ sequence before GGCUCCUGAGGCGGCCGUACAAUCCUCGGCAGUGUCCUGAGACUGUAUGGUCAG CUCAGCCCAUG (14) (Metabion, Germany). According to manufacturer and Anderson et al., the IRE was folded in $60 \mathrm{mM} \mathrm{KCl,} 6 \mathrm{mM} \mathrm{HEPES,} 0.2 \mathrm{mM} \mathrm{MgCl}_{2}$ via heating to $90^{\circ} \mathrm{C}$ for 2 minutes and cooling on ice for 5 min. $2 \mu$ of $0.1 \mu \mathrm{M}$ RNA was mixed with $20 \mu \mathrm{g}$ cell lysate or $1 \mu \mathrm{M}$ recombinant IRP1 and $10 \mu \mathrm{M}$ recombinant Trx1 or $300 \mathrm{mM}$ DTT or $10 \mathrm{mM}$ $\beta$-mercaptoethanol in $20 \mathrm{mM}$ HEPES pH 7.4. Samples were incubated with $20 \mu \mathrm{g} / \mathrm{ml} \mathrm{BSA}$ for 10 minutes at RT followed by addition of heparin to $0.5 \mu \mathrm{g} / \mu \mathrm{l}$. For supershift, $1 \mu \mathrm{l}$ of $1: 20$ diluted selfmade $\alpha$-IRP1-antibodies (65) was added for another 2 minutes. SDS PAGE was run as native gel (native PAGE buffer: $25 \mathrm{mM}$ Tris, $192 \mathrm{mM}$ Glycine, $\mathrm{pH}$ 8.3) at $120 \mathrm{~V}$ in the dark. Afterwards the probe was detected at $700 \mathrm{~nm}$ using Odyssey Infrared Imaging System (LI-COR Bioscience).

The 2D diagonal redox SDS PAGE was performed modifying the protocol described by (66). In brief, $40 \mu \mathrm{g}$ cell lysate was mixed with sample buffer, denatured for $10 \mathrm{~min}$ at $96^{\circ} \mathrm{C}$ before it was separated at a 4-20\% PROTEAN TGX stain-free gel (BioRad) at $200 \mathrm{~V}$ for 30 min. The protein lane was cut out and reduced in 250 mM DTT in 1-fold sample buffer at $65^{\circ} \mathrm{C}$. The gel was washed in 1-fold sample buffer, before the proteins were alkylated for 20 min at a reciprocal shaker using $100 \mathrm{mM}$ NEM in 1-fold sample buffer. The gel was washed in 1-fold sample buffer again before it was placed at a 4-20\% PROTEAN TGX IPG gel. A molecular weight marker was added and the gel lane was overlaid with $1 \%$ agarose in 1-fold sample buffer. The proteins were separated at $50 \mathrm{~V}$ for $10 \mathrm{~min}$, followed by $200 \mathrm{~V}$ for $30 \mathrm{~min}$.

The protein content of all gels (and later the blots) was imaged after activation using BioRads stain-free technology with the ChemiDoc XRS+ System. Western blotting was performed using the Trans-Blot Turbo RTA Transfer Kit (BioRad), according to the manufacturers protocol using PVDF membranes. Membranes were blocked with Tris- 
buffered saline containing $0.05 \%$ Tween $20,5 \%$ nonfat milk powder and 1\% BSA for $1 \mathrm{~h}$ at RT and were incubated with specific primary antibodies against Trx1 (57), GPAT (kindly supplied by R. Lill, Marburg Germany), IRP1 (abcam ab126595 for 1D gels and for 2D gels see reference (65), ferritin (abcam ab75973), and the transferrin receptor (Life technologies $13-6890$ ) at $4^{\circ} \mathrm{C}$ overnight. Using horseradish peroxidase (HRP)-coupled secondary antibodies (BioRad) and the enhanced chemiluminescence method antigenantibody complexes were detected by the ChemiDoc XRS+ System (BioRad). The densitometric analysis was performed using ImageJ and the ImageLab 5.0 Software (BioRad).

\section{Identification of interaction partners}

Co-immunoprecipitation of IRP1 and Trx1 was performed using CnBr activated sepharose. $100 \mathrm{mg}$ sepharose beads were incubated with IRP1 antibodies (26) corresponding to the equivalent of $1 \mathrm{ml}$ serum. After washing steps with PBS, the sepharose beads were blocked with $1 \mathrm{M}$ ethanol amine. $20 \mu \mathrm{l}$ antibody conjugated sepharose beads were incubated with $1 \mathrm{mg}$ protein lysate at $4{ }^{\circ} \mathrm{C}$ over night. After removing unbound proteins, the sepharose and bound proteins were denatured for $10 \mathrm{~min}$ at $95^{\circ} \mathrm{C}$ and $\operatorname{Trx} 1$ was stained after performing a reducing SDS PAGE and Western blotting.

The intermediate trapping was performed by immobilizing Trx1C35S on a HisTrap column. Following reduction with $10 \mathrm{mM}$ DTT, 10-20 mg HeLa cell lysate were loaded on the column. Following extensive washing, trapped proteins were eluted with $10 \mathrm{mM}$ DTT, were precipitated over night at $4^{\circ} \mathrm{C}$ with $20 \%$ TCA and were centrifuged for 15 min at 13.000 rpm and $4^{\circ} \mathrm{C}$. The pellet was washed with ice cold acetone, centrifuged again and resuspended in lysis buffer. The presence of IRP1 was analyzed by SDS-Page and Western Blotting using the IRP1 antibody described in (26). 


\section{Molecular modeling}

The suggested conformational changes required for the binding of the FeS cofactor to human Trx1 were modeled using SPDBV $(67,68)$. Based on the structure of reduced human Trx1 (pdb entry 1ert), we scanned the loop database for potential alternative conformations of the loop connecting alpha helix 3 and strand 3 of the central beta-sheet. Glu70 and the cis-Pro75 were used as anchoring residues. The best fit was obtained with a model loop obtained from structure 2nacA (residues 25-28). The resulting structure was relaxed by energy minimization. The integrity and quality of the structure was confirmed using ProSA-web (69), the z-score of -6.9 was within the range of scores typically found for native proteins of this size. The proposed holo-structure of dimeric Trx1 was modeled based on the holo-structures of human Grx2 (2ht9) and human Grx5 (2wul), Electrostactic calculations were performed as described in (46). Apo-IRP1, i.e. the missing loop containing cysteinyl residues 503 and 506, was modeled using Swiss Model (https://swissmodel.expasy.org/) with pdb entry 3sn2 as template. Structures were displayed using UCSF Chimera (https://www.cgl.ucsf.edu/chimera/).

\section{Phylogenetic analysis}

Sequences for Trx1 and IRP1/Aco1 were collected from the uniprot.org and pubmed databases. Alignments and the radial phylogenetic tree were created using the CLC Sequence Viewer 8. Alignments were used to analyze the presence of the active site Cys residues as well as the extra Cys73. 


\section{Acknowledgements}

The authors wish to thank C.A. Helm and A. Gröning (Greifswald) for help with the differential scanning calorimetry, Elias Arnér (Stockholm Sweden) for providing mammalian TrxR, and Rick Eisenstein (Madison, USA) for helpful discussions. This work was supported by grants from Plan Cancer (to JMM: $\mathrm{n}^{\circ}$ 18CB010-00) and the Deutsche Forschungsgemeinschaft, in particular the Priority Program SPP 1927 (to CB: BE 3259/51,2, BE 3259/6-1; to CHL: LI 984/3-1,2, LI 984/4-1, GRK1947-A1, to CSM: SCHU 1480/41, and to VS: SCHU 1251/17-1,2).

\section{Author contributions}

C.B., E.M.H., C.U., and C.H.L. performed biochemical and cellular experiments, E.M.H., S.S., Y.B., and O.H. cloned and purified Trx mutants, L.M.J., C.S.M., and V.S. performed Mössbauer spectroscopy, R.N. and C.S. synthesized and provided $\left(\mathrm{NH}_{4}\right)_{2}$ ${ }^{57} \mathrm{Fe}\left(\mathrm{SO}_{4}\right)_{2} \cdot 6 \mathrm{H}_{2} \mathrm{O}$, C.H.L. performed bioinformatic analysis, J.M.M. provided critical input, C.B., E.M.H., and C.H.L. wrote the manuscript, all authors approved the text.

\section{Declaration of Interests}

The authors declare no competing interests. 


\section{References}

1. C. H. Lillig, A. Holmgren, Thioredoxin and Related Molecules From Biology to Health and Disease. Antioxid. Redox Signal. 9, 25-47 (2007).

2. T. C. Laurent, E. C. Moore, P. Reichard, Enzymatic synthesis of deoxyribonucleotides. iv. isolation and characterization of thioredoxin, the hydrogen donor from Escherichia coli B. $J$. Biol. Chem. 239, 3436-44 (1964).

3. B. B. Buchanan, A. Holmgren, J.-P. Jacquot, R. Scheibe, Fifty years in the thioredoxin field and a bountiful harvest. Biochim. Biophys. Acta 1820, 1822-1829 (2012).

4. E.-M. Hanschmann, J. R. Godoy, C. Berndt, C. Hudemann, C. H. Lillig, Thioredoxins, glutaredoxins, and peroxiredoxins--molecular mechanisms and health significance: from cofactors to antioxidants to redox signaling. Antioxid. Redox Signal. 19, 1539-1605 (2013).

5. R. Lill, U. Mühlenhoff, Maturation of iron-sulfur proteins in eukaryotes: mechanisms, connected processes, and diseases. Annu. Rev. Biochem. 77, 669-700 (2008).

6. H. Sies, C. Berndt, D. P. Jones, Oxidative Stress. Annu. Rev. Biochem. 86, 715-748 (2017).

7. C. P. Anderson, M. Shen, R. S. Eisenstein, E. A. Leibold, Mammalian iron metabolism and its control by iron regulatory proteins. Biochim Biophys Acta 1823, 1468-1483 (2012).

8. M. U. Muckenthaler, B. Galy, M. W. Hentze, Systemic iron homeostasis and the ironresponsive element/iron-regulatory protein (IRE/IRP) regulatory network. Annu. Rev. Nutr. 28, 197-213 (2008).

9. M. L. Wallander, E. A. Leibold, R. S. Eisenstein, Molecular control of vertebrate iron homeostasis by iron regulatory proteins. Biochim. Biophys. Acta 1763, 668-689 (2006).

10. A. A. Salahudeen, et al., An E3 ligase possessing an iron-responsive hemerythrin domain is a regulator of iron homeostasis. Science 326, 722-726 (2009).

11. A. A. Vashisht, et al., Control of iron homeostasis by an iron-regulated ubiquitin ligase. Science 326, 718-721 (2009).

12. M. Sanchez, B. Galy, M. U. Muckenthaler, M. W. Hentze, Iron-regulatory proteins limit hypoxia-inducible factor-2alpha expression in iron deficiency. Nat. Struct. Mol. Biol. 14, 420 426 (2007).

13. M. Zimmer, et al., Small-molecule inhibitors of HIF-2a translation link its 5'UTR ironresponsive element to oxygen sensing. Mol. Cell 32, 838-848 (2008).

14. S. A. Anderson, et al., The IRP1-HIF-2 $\alpha$ axis coordinates iron and oxygen sensing with erythropoiesis and iron absorption. Cell Metab. 17, 282-290 (2013).

15. M. C. Ghosh, et al., Deletion of iron regulatory protein 1 causes polycythemia and pulmonary hypertension in mice through translational derepression of HIF2 $\alpha$. Cell Metab. 17, 271-281 (2013).

16. N. Wilkinson, K. Pantopoulos, IRP1 regulates erythropoiesis and systemic iron homeostasis by controlling HIF2 $\alpha$ mRNA translation. Blood 122, 1658-1668 (2013). 
bioRxiv preprint doi: https://doi.org/10.1101/2020.08.04.235721; this version posted August 5, 2020. The copyright holder for this preprint (which was not certified by peer review) is the author/funder. All rights reserved. No reuse allowed without permission.

17. P. H. Maxwell, et al., The tumour suppressor protein VHL targets hypoxia-inducible factors for oxygen-dependent proteolysis. Nature 399, 271-275 (1999).

18. V. H. Haase, Regulation of erythropoiesis by hypoxia-inducible factors. Blood Rev. 27, 41-53 (2013).

19. B. Keith, R. S. Johnson, M. C. Simon, HIF1 $\alpha$ and HIF2 $\alpha$ : sibling rivalry in hypoxic tumour growth and progression. Nat. Rev. Cancer 12, 9-22 (2011).

20. M.-E. Pandelia, N. D. Lanz, S. J. Booker, C. Krebs, Mössbauer spectroscopy of Fe/S proteins. Biochim. Biophys. Acta 1853, 1395-1405 (2015).

21. H. Beinert, R. H. Holm, E. Münck, Iron-sulfur clusters: nature’s modular, multipurpose structures. Science 277, 653-659 (1997).

22. P. Gütlich, E. Bill, A. X. Trautwein, Mössbauer Spectroscopy and Transition Metal Chemistry: Fundamentals and Applications (Springer-Verlag, 2011) (August 15, 2018).

23. N. Khoroshilova, C. Popescu, E. Münck, H. Beinert, P. J. Kiley, Iron-sulfur cluster disassembly in the FNR protein of Escherichia coli by O2: [4Fe-4S] to [2Fe-2S] conversion with loss of biological activity. Proc. Natl. Acad. Sci. 94, 6087-6092 (1997).

24. S. Ollagnier, et al., Assembly of 2Fe-2S and 4Fe-4S Clusters in the Anaerobic Ribonucleotide Reductase from Escherichia coli. J. Am. Chem. Soc. 121, 6344-6350 (1999).

25. C. A. Royer, Probing Protein Folding and Conformational Transitions with Fluorescence. Chem. Rev. 106, 1769-1784 (2006).

26. P. Haunhorst, C. Berndt, S. Eitner, J. R. Godoy, C. H. Lillig, Characterization of the human monothiol glutaredoxin 3 (PICOT) as iron-sulfur protein. Biochem. Biophys. Res. Commun. 394, 372-376 (2010).

27. C. H. Lillig, et al., Characterization of human glutaredoxin 2 as iron-sulfur protein: A possible role as redox sensor. Proc. Natl. Acad. Sci. 102, 8168-8173 (2005).

28. O. Stehling, et al., Investigation of iron-sulfur protein maturation in eukaryotes. Methods Mol. Biol. Clifton NJ 372, 325-342 (2007).

29. C. Berndt, et al., How Does Iron Sulfur Cluster Coordination Regulate the Activity of Human Glutaredoxin 2? Antioxid. Redox Signal. 9, 151-157 (2007).

30. C. Johansson, K. L. Kavanagh, O. Gileadi, U. Oppermann, Reversible sequestration of active site cysteines in a $2 \mathrm{Fe}-2 \mathrm{~S}$-bridged dimer provides a mechanism for glutaredoxin 2 regulation in human mitochondria. J. Biol. Chem. 282, 3077-82 (2007).

31. K. Lepka, et al., Iron-sulfur glutaredoxin 2 protects oligodendrocytes against damage induced by nitric oxide release from activated microglia. Glia 65, 1521-1534 (2017).

32. L. Bräutigam, et al., Vertebrate-specific glutaredoxin is essential for brain development. Proc. Natl. Acad. Sci. U. S. A. 108, 20532-20537 (2011).

33. L. Bräutigam, et al., Glutaredoxin regulates vascular development by reversible glutathionylation of sirtuin 1. Proc. Natl. Acad. Sci. U. S. A. 110, 20057-20062 (2013).

34. M. Gellert, et al., The cytosolic isoform of glutaredoxin 2 promotes cell migration and invasion. Biochim. Biophys. Acta BBA - Gen. Subj. 1864, 129599 (2020). 
bioRxiv preprint doi: https://doi.org/10.1101/2020.08.04.235721; this version posted August 5, 2020. The copyright holder for this preprint (which was not certified by peer review) is the author/funder. All rights reserved. No reuse allowed without permission.

35. C. Johansson, et al., The crystal structure of human GLRX5: iron-sulfur cluster co-ordination, tetrameric assembly and monomer activity. Biochem. J. 433, 303-311 (2011).

36. C. Berndt, C. H. Lillig, Glutathione, Glutaredoxins, and Iron. Antioxid. Redox Signal. 27, 1235-1251 (2017).

37. N. Rouhier, J. Couturier, M. K. Johnson, J.-P. Jacquot, Glutaredoxins: roles in iron homeostasis. Trends Biochem. Sci. 35, 43-52 (2010).

38. D. Trnka, et al., Molecular basis for the distinct functions of redox-active and FeS-transfering glutaredoxins. Nat. Commun. 11, 3445 (2020).

39. K. Stegmaier, et al., Apd1 and Aim32 Are Prototypes of Bishistidinyl-Coordinated Non-Rieske [2Fe-2S] Proteins. J. Am. Chem. Soc. 141, 5753-5765 (2019).

40. D. Su, C. Berndt, D. E. Fomenko, A. Holmgren, V. N. Gladyshev, A conserved cis-proline precludes metal binding by the active site thiolates in members of the thioredoxin family of proteins. Biochemistry 46, 6903-6910 (2007).

41. F. Zannini, et al., Mitochondrial Arabidopsis thaliana TRXo Isoforms Bind an Iron-Sulfur Cluster and Reduce NFU Proteins In Vitro. Antioxid. Basel Switz. 7 (2018).

42. L. Oliveira, C. Bouton, J. C. Drapier, Thioredoxin activation of iron regulatory proteins. Redox regulation of RNA binding after exposure to nitric oxide. J. Biol. Chem. 274, 516-521 (1999).

43. E. Soum, et al., Peroxynitrite and nitric oxide differently target the iron-sulfur cluster and amino acid residues of human iron regulatory protein 1. Biochemistry 42, 7648-7654 (2003).

44. C. C. Philpott, D. Haile, T. A. Rouault, R. D. Klausner, Modification of a free Fe-S cluster cysteine residue in the active iron-responsive element-binding protein prevents RNA binding. J. Biol. Chem. 268, 17655-17658 (1993).

45. C. Berndt, J.-D. Schwenn, C. H. Lillig, The specificity of thioredoxins and glutaredoxins is determined by electrostatic and geometric complementarity. Chem. Sci. 6, 7049-7058 (2015).

46. M. Gellert, et al., Substrate specificity of thioredoxins and glutaredoxins - towards a functional classification. Heliyon 5, e02943 (2019).

47. D. J. Haile, Regulation of genes of iron metabolism by the iron-response proteins. Am J Med Sci 318, 230-240 (1999).

48. S. Mueller, Iron regulatory protein 1 as a sensor of reactive oxygen species. BioFactors Oxf. Engl. 24, 171-181 (2005).

49. C. N. Lok, P. Ponka, Identification of a hypoxia response element in the transferrin receptor gene. J. Biol. Chem. 274, 24147-24152 (1999).

50. S. R. Smith, M. C. Ghosh, H. Ollivierre-Wilson, W. Hang Tong, T. A. Rouault, Complete loss of iron regulatory proteins 1 and 2 prevents viability of murine zygotes beyond the blastocyst stage of embryonic development. Blood Cells. Mol. Dis. 36, 283-287 (2006).

51. E. S. Hanson, E. A. Leibold, Regulation of iron regulatory protein 1 during hypoxia and hypoxia/reoxygenation. J. Biol. Chem. 273, 7588-7593 (1998). 
bioRxiv preprint doi: https://doi.org/10.1101/2020.08.04.235721; this version posted August 5, 2020. The copyright holder for this preprint (which was not certified by peer review) is the author/funder. All rights reserved. No reuse allowed without permission.

52. E. S. Hanson, L. M. Foot, E. A. Leibold, Hypoxia post-translationally activates iron-regulatory protein 2. J. Biol. Chem. 274, 5047-5052 (1999).

53. T. Christova, D. M. Templeton, Effect of hypoxia on the binding and subcellular distribution of iron regulatory proteins. Mol. Cell. Biochem. 301, 21-32 (2007).

54. I. Toth, L. Yuan, J. T. Rogers, H. Boyce, K. R. Bridges, Hypoxia alters iron-regulatory protein1 binding capacity and modulates cellular iron homeostasis in human hepatoma and erythroleukemia cells. J. Biol. Chem. 274, 4467-4473 (1999).

55. M. R. Pawlus, C.-J. Hu, Enhanceosomes as integrators of hypoxia inducible factor (HIF) and other transcription factors in the hypoxic transcriptional response. Cell. Signal. 25, 1895-1903 (2013).

56. E. Pourcelot, et al., The iron regulatory proteins are defective in repressing translation via exogenous 5' iron responsive elements despite their relative abundance in leukemic cellular models. Met. Integr. Biometal Sci. 10, 639-649 (2018).

57. J. R. Godoy, et al., Redox atlas of the mouse. Immunohistochemical detection of glutaredoxin-, peroxiredoxin-, and thioredoxin-family proteins in various tissues of the laboratory mouse. Biochim. Biophys. Acta 1810, 2-92 (2011).

58. A. Janoschka, G. Svenconis, V. Schünemann, A closed cycle-cryostat for high-field Mössbauer spectroscopy. J. Phys. Conf. Ser. 217, 012005 (2010).

59. H. P. Gunnlaugsson, Spreadsheet based analysis of Mössbauer spectra. Hyperfine Interact. 237, 79 (2016).

60. V. Schünemann, H. Winkler, Structure and dynamics of biomolecules studied by Mössbauer spectroscopy. Rep. Prog. Phys. 63, 263 (2000).

61. H. Montgomery, B. Morosin, J. J. Natt, A. M. Witkowska, E. C. Lingafelter, The crystal structure of Tutton's salts. VI. Vanadium(II), iron(II) and cobalt(II) ammonium sulfate hexahydrates. Acta Crystallogr. 22, 775-780 (1967).

62. G. Jander, E. Blasius, Lehrbuch der analytischen und präparativen anorganischen Chemie: mit 45 Tabellen, 14., neu bearb. Aufl. / von Joachim Strähle und Eberhard Schweda (Hirzel, 1995).

63. A. Biederbick, et al., Role of human mitochondrial Nfs1 in cytosolic iron-sulfur protein biogenesis and iron regulation. Mol. Cell. Biol. 26, 5675-5687 (2006).

64. E. S. Arnér, A. Holmgren, Measurement of thioredoxin and thioredoxin reductase. Curr. Protoc. Toxicol. Chapter 7, Unit 7.4. (2001).

65. P. Haunhorst, et al., Crucial function of vertebrate glutaredoxin 3 (PICOT) in iron homeostasis and hemoglobin maturation. Mol. Biol. Cell 24, 1895-1903 (2013).

66. S. Stöcker, M. Maurer, T. Ruppert, T. P. Dick, A role for 2-Cys peroxiredoxins in facilitating cytosolic protein thiol oxidation. Nat. Chem. Biol. 14, 148-155 (2018).

67. N. Guex, M. C. Peitsch, SWISS-MODEL and the Swiss-PdbViewer: an environment for comparative protein modeling. Electrophoresis 18, 2714-2723 (1997).

68. T. Schwede, J. Kopp, N. Guex, M. C. Peitsch, SWISS-MODEL: An automated protein homology-modeling server. Nucleic Acids Res. 31, 3381-3385 (2003). 
bioRxiv preprint doi: https://doi.org/10.1101/2020.08.04.235721; this version posted August 5, 2020. The copyright holder for this preprint (which was not certified by peer review) is the author/funder. All rights reserved. No reuse allowed without permission.

69. M. Wiederstein, M. J. Sippl, ProSA-web: interactive web service for the recognition of errors in three-dimensional structures of proteins. Nucleic Acids Res. 35, W407-410 (2007). 


\section{Tables}

Table 1 Mössbauer parameters of reconstituted holo-Trx1.

Holo-Trx1 was reconstituted in vitro and concentrated to $2.5 \mathrm{mM}$. The protein was frozen in liquid nitrogen and analyzed by Mössbauer spectroscopy as outlined in the experimental procedures, see also Fig. 1.

\begin{tabular}{ccc}
\hline parameter & fraction 1 & fraction 2 \\
\hline$\delta\left(\mathrm{mm} \mathrm{s}^{-1}\right)$ & without external magnetic field & \\
$\Delta E_{\mathrm{Q}}\left(\mathrm{mm} \mathrm{s}^{-1}\right)$ & $0.35 \pm 0.02$ & $0.56 \pm 0.02$ \\
$\Gamma\left(\mathrm{mm} \mathrm{s}^{-1}\right)$ & $0.66 \pm 0.03$ & $0.72 \pm 0.03$ \\
area $(\%)$ & $0.33 \pm 0.03$ & $0.43 \pm 0.03$ \\
\hline
\end{tabular}




\section{Figure legends}

Figure 1 Identification of a $[2 \mathrm{Fe}-2 \mathrm{~S}]^{2+}$ cluster in human and mouse Trx1. A) UV-Vis spectroscopy of recombinantly expressed monomeric and dimeric human Trx1 and mouse Trx1 after purification. Inset: Chromatogram of the gelfiltration chromatography separating monomeric apo-Trx1 and dimeric holo-Trx1. B) Mössbauer spectra of reconstituted human Trx1 in the absence of an external magnetic field. The simulated spectra of fractions 1 and 2 (see text and table 1) were included on top of the recorded spectra. C) UV-Vis spectroscopy after purification of recombinant human Trx1 with individually mutated cysteinyl residues as indicated. D) Model of the holo-Trx1 complex. E-F) CD spectra (E) and fluorescence spectra at $294 \mathrm{~nm}$ excitation (Trp fluorescence, F) of monomeric apoTrx1 and dimeric holo-Trx1. D) of apo- and holo-Trx1.

Figure 2 Influence of Trx1 on the iron-depletion and hypoxia response. Analysis of the protein levels of Trx1, iron regulatory protein 1 (IRP1), glutamine phosphoribosylpyrophosphate amidotransferase (GPAT), transferrin receptor (TfR), ferritin (Fer), and hypoxia-induced factor $2 \alpha(\mathrm{HIF} 2 \alpha)$ in cells depleted of Trx1 by siRNA treatment. The left column displays representative Western blots (left: control (siCtr), right: Trx1depleted (siTrx1); upper lane: hypoxic conditions $\left(1 \% \mathrm{O}_{2}\right)$, lower lane: hypoxic and ironlimiting conditions (+ iron chelator deferoxamine (DFO)). The right column shows the quantitative analysis of the Western blots by densitometry (upper column pair: - DFO, lower column pair: + DFO). In each case, the values were normalized to the protein levels from cells with wildtype Trx1 levels without DFO treatment ( $n \geq 3, \pm S D)$.

Figure 3 Trx1 reduces IRP1 and regulates IRP1 binding to Hif2 $\alpha$-IRE. A) Reduction of different concentrations of IRP1 as indicated by Trx1 in vitro in a coupled kinetic assay with 
rat TrxR1 and NADPH measuring NADPH consumption at $340 \mathrm{~nm}$. The solid line is a nonlinear curve fitting of the data points $(n=4$, mean $\pm S D)$ to the Michaelis-Menten equation. B-C) Diagonal 2-dimensional SDS PAGE under non-reducing (first dimension) and reducing conditions (second dimension) reveals the redox state of IRP1 in control (B) and Trx1-depleted HeLa cells (C) cultivated at $1 \% \mathrm{O}_{2}$ in the presence of deferoxamine (DFO). The pictures show overlays of the total amount of proteins in blue (Coomassie staining) and a Western blot staining IRP1 in black. D-E) Electrophoretic shift assays (EMSAs) using a labeled Hif2 $\alpha-I R E$ probe. D) EMSAs with extracts of HeLa cells \pm hypoxic $\left(1 \% \mathrm{O}_{2}\right)$ and iron-limiting (+ iron chelator desferoxamine (DFO)) conditions \pm Trx1 depletion (siTrx1). Quantification shows mean \pm SD of triplicates of two independent biological samples each. E) Recombinant IRP1 ( $n=3)$ was incubated with apo-Trx (n=4), holo-Trx (after in vitro reconstitution, $\mathrm{n}=3$ ), Trx-Fe (Trx1 incubated with $\left(\mathrm{NH}_{4}\right)_{2} \mathrm{Fe}\left(\mathrm{SO}_{4}\right)_{2}, \mathrm{n}=3$ ), and FeS control (in vitro reconstitution mixture without $\operatorname{Tr} 1, \mathrm{n}=1$ ), shown is mean \pm SD.

Figure 4 Iron binding in Trx family proteins. A) Alignment of the structures of human holo-Grx2 (pdb entry: 2ht9), holo-Grx5 (2wul), and holo-Trx1 (obtained by modeling in this study) depicting the position of the thiol groups recruited for binding of the [2Fe-2S] clusters. The FeS clusters bound to Grx2 and Grx5 were included in the image. B) Model for the activation of Trx1 and IRP1 by FeS cluster disassembly and redox regulation, for details see text. 
Fig. 1
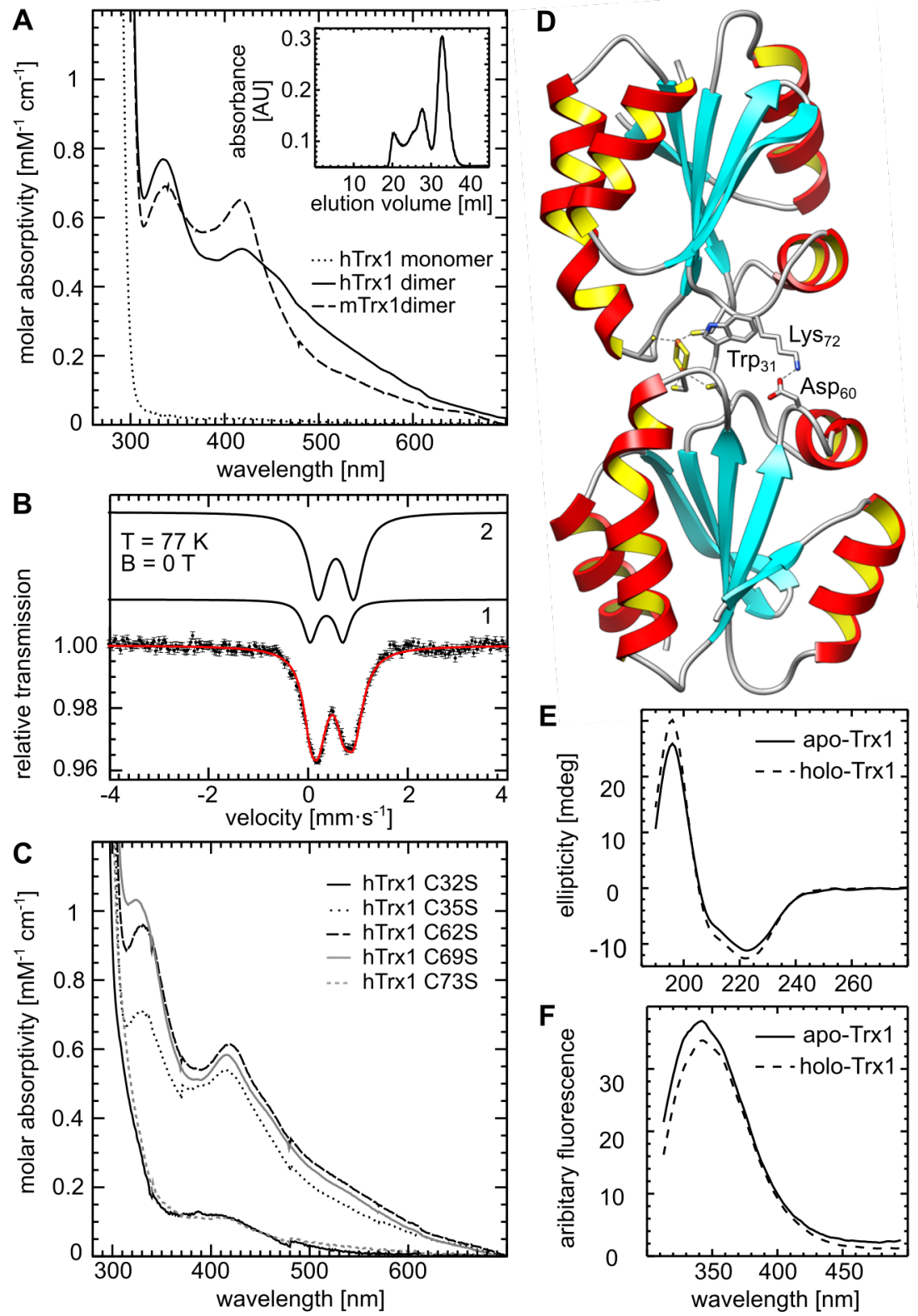
bioRxiv preprint doi: https://doi.org/10.1101/2020.08.04.235721; this version posted August 5, 2020. The copyright holder for this preprint (which was not certified by peer review) is the author/funder. All rights reserved. No reuse allowed without permission.

Fig. 2

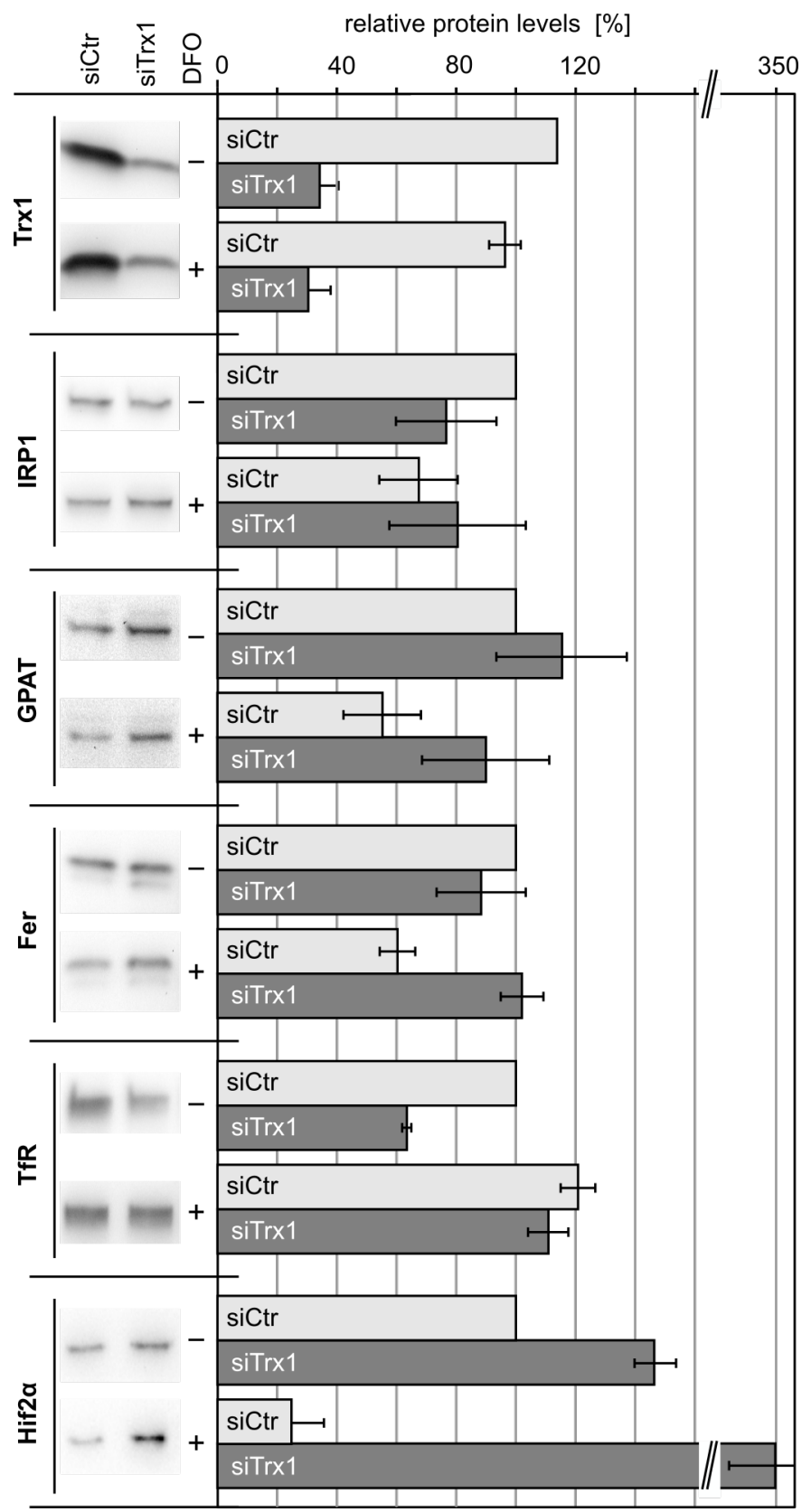


Fig. 3
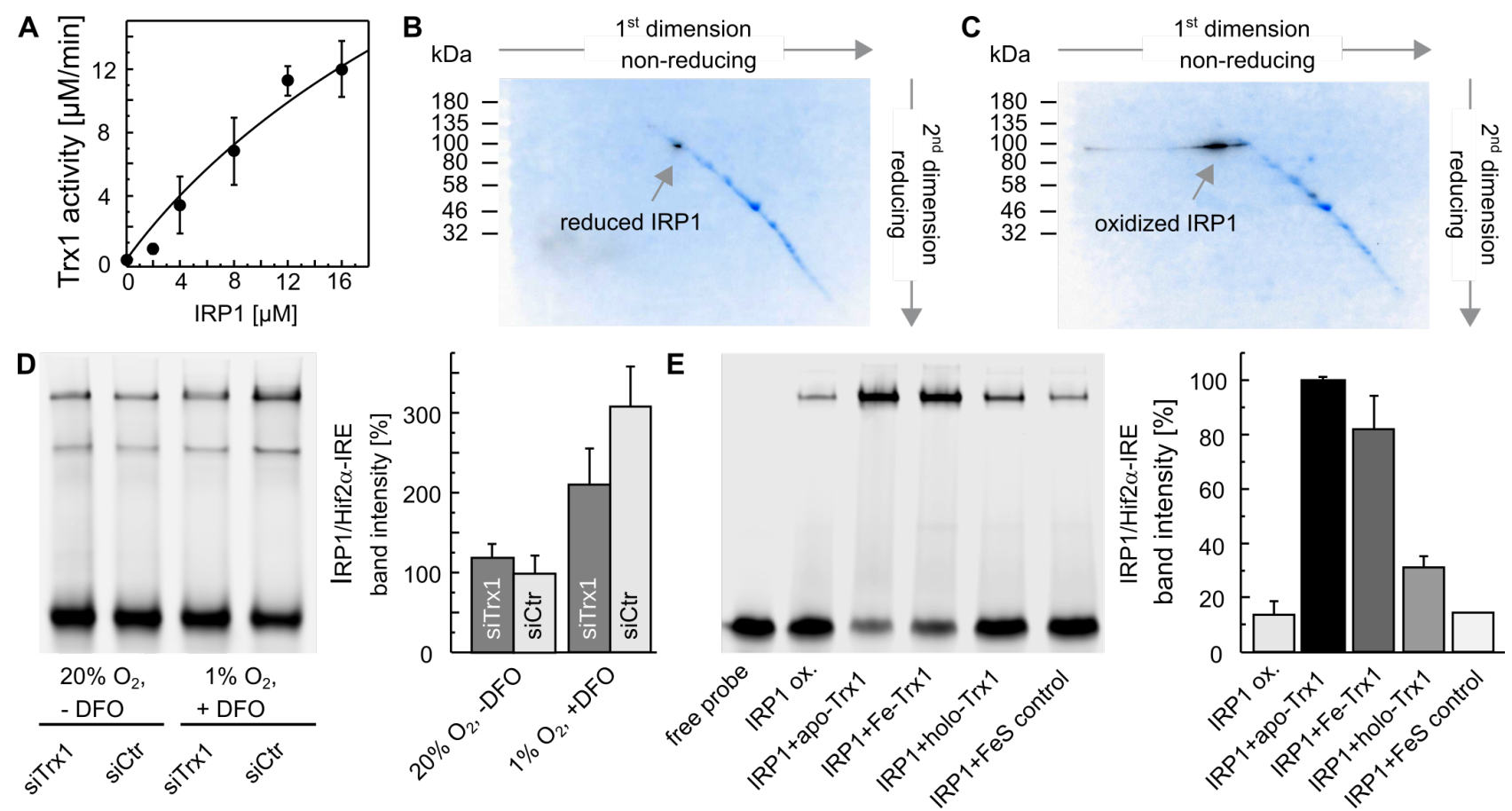
bioRxiv preprint doi: https://doi.org/10.1101/2020.08.04.235721; this version posted August 5, 2020. The copyright holder for this preprint (which was not certified by peer review) is the author/funder. All rights reserved. No reuse allowed without permission.

Fig. 4

A

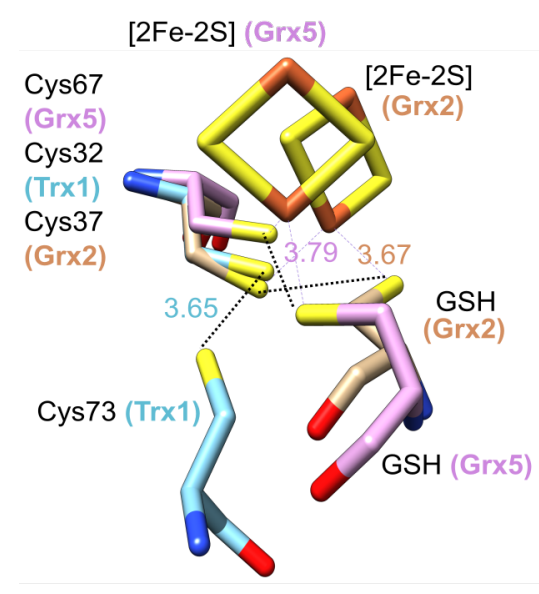

B

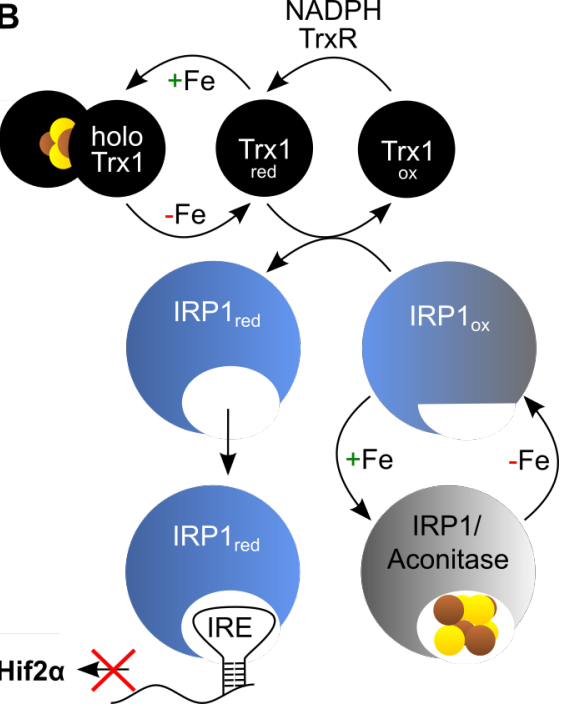

